Five valuable scholarships offered by Price Bros. \& Co., Ltd., for competition in the department of forestry at the University of New Brunswick have been awarded, Dr. A. W. Trueman, president of the university, announced on November 23.

The winners of the scholarships, the total value of which is $\$ 2,000$, are: Donald A. Linton, 99 Hazen St., Saint John, N.B.; James S. Lawyer, Washington, N.J.; David Etheridge, St. Eustache sur le Lac, Que.; Wallace C. Bridcut, Valleyfield, Que.; and Gerald K. Seed, Black Hawk, Ont.

It is of interest that Linton, Etheridge and Seed, all of whom are senior students, are married veteran students. Lawyer and Bridcut, who are both junior students, are single. These scholarship awards illustrate the fact that the majority of the veteran students at U.N.B. have reached the senior year of their courses-if indeed they have not already graduated.

Dr. J. M. Gibson, dean of forestry at U.N.B., pointed out that sons of employees of Price Bros. receive preference over other applicants, but none competed this year. Scholarship, moral standing and financial need are all taken into consideration by the forestry faculty which recommends students for the awards.

This is the second year that the scholarships, each of which has a value of $\$ 400$, have been offered. The headquarters of the corporation which founded this outstanding scholarship plan at U.N.B. are in Quebec City.

The Viscount Bennett scholarships for forestry students at the University of New Brunswick have been awarded for $1949-50$ to E. L. Underhill, a senior, and to D. C. MacGregor, a junior. This announcement was made on November 25 by Dr. W. A. Trueman, president.

Underhill is from Blackville, N.B., and MacGregor's home is at 255 Granville Ave., Eastview, Ont. Both are veteran students and Underhill has a young daughter.

As beneficiary under a trust fund founded by the late Viscount Bennett, U.N.B. receives an income which provides the two annual scholarships. Each has a value of $\$ 100$.

\title{
FORESTRY ALUMNI, UNIVERSITY OF TORONTO
}

A most enjoyable Forestry Alumni dinner was held in Hart House, University of Toronto, on October 26th. The dinner attended by over 100 grey, greying and not-grey-at-all graduates, was tastefully arranged and presented, and those who were responsible for the organizing deserve more than a word of praise from their fellow graduates.

Dr. Sydney Smith, President of the University, J. W. B. Sisam, Dean of the Faculty of Forestry, and W. A. Osbourne, President of the University of Toronto Alumni Association gave informative and interesting addresses.

A short business session chaired by G. W. Phipps, Chairman of the reorganized University of Toronto Forestry Alumni Association, followed the dinner. Proposed future activities were reviewed, committees appointed, and plans made for the continuance of the recently initiated membership campaign.

This was the largest gathering ever of the Toronto Forestry Alumni Association. 